\title{
An International Investigation Of Conservative Bias And Accounting Practices
}

Joan Hollister, State University of New York - New Paltz, USA Victoria Shoaf, St. John's University, USA

\begin{abstract}
This paper investigates the relationship between conservatism of accrual accounting and the relationship described by Ohlson (1995) and Feltham and Ohlson (1995) between future profitability and both current profitability and the growth in net operating assets. To evaluate the conservatism of accounting practices, we construct an annual index for six countries based on the relationship of depreciation and amortization expense and research and development costs expensed to the underlying long-term operating assets. As in Fairfield, Whisenant, and Yohn (2003, hereafter FWY), the growth in net operating assets is disaggregated into growth in longterm net operating assets and accruals. We focus on the accrual practices used by companies listed on the primary exchanges in six countries, to assess whether there are country-specific accounting differences that affect the profitability relationship, and whether such differences are related to the negative earnings persistence of the components of growth in net operating assets documented by FWY for the US. Following FWY, we also disaggregate growth in net operating assets into growth in net long-term operating assets and growth in net short-term operating assets to assess their relative persistence. Our findings suggest that variation in the conservative bias in accounting practices affects the impact of the growth in short-term and long-term net operating assets differently, providing evidence that the accrual anomaly is not just another representation of the growth anomaly. Finally, we employ the Mishkin (1983) model to extend internationally the FWY findings of market inefficiency with regards to the impounding in stock prices information conveyed by investments in short-term and long-term net operating assets.
\end{abstract}

Keywords: conservative bias, international differences, accounting accruals, growth anomaly, earnings persistence

\section{INTRODUCTION}

$\mathcal{J}$ his paper investigates the extent to which international variation in the conservatism of accrual accounting practices influences the relationship described by Ohlson (1995) and Feltham and Ohlson (1995) between future profitability and both current profitability and the growth in net operating assets. In their related study, Fairfield, Whisenant, and Yohn (2003, hereafter FWY), disaggregate the growth in net operating assets into its two primary components; i.e. growth in long-term net operating assets and accruals. They attribute their finding of negative earnings persistence for both of these components of growth in net operating assets to diminishing marginal returns on investment or the conservative bias of accounting, as defined by Penman (2004), or both. They do not attempt to ascertain whether one or the other of these two possible explanations is more likely. In this study, we consider the contribution of one of these explanations, the conservative bias of accounting, by investigating the results for accounting regimes with different levels of conservative accounting practices, specifically with regard to their cost-allocation practices for long-term operating assets. We focus on the accrual practices used by companies listed on the primary exchanges in the United States (US) and five other countries-Canada, France, Germany, Japan, and the United Kingdom (UK) - to assess whether there are country-specific differences in accounting for depreciation, amortization and research and development costs that affect the profitability relationship, and whether such differences are related to the negative earnings persistence of the components of growth in net operating assets documented by FWY for the US. 
To evaluate the conservatism of accounting practices, we construct an annual index for each country based on the relationship of depreciation and amortization expense and research and development costs expensed to the underlying long-term operating assets. In examining the indices for each country by year, from 1996 through 2003, we observe a statistically significant change in the mean and median indices for most countries around the year 2000. While this change is undoubtedly related to a number of economic and commercial circumstances, we attribute a significant part of it to the acceptance by the International Organization of Securities Commissions (IOSCO) of the "core" international accounting standards and the growing movement toward adoption of, or convergence with, those standards.

While we expect to find diminishing marginal returns to growth in investments across countries and across years, country-specific variation in the impact of the growth in net operating assets on future earnings consistent with the level of conservatism of accounting would provide support for conservative bias as an explanation for the growth anomaly described by FWY. We evaluate the Ohlson (1995) model for each country for the two time periods and, based on our index, we observe some significant predicted differences between countries in the pre2000 time period and for individual countries between the pre-2000 and post-2000 time periods. Our results provide evidence for the conservative bias explanation put forth by FWY for the growth anomaly. Following FWY, we then disaggregate growth in net operating assets into growth in net long-term operating assets and growth in net shortterm operating assets (accruals) to assess their relative persistence. Our findings suggest that variation in the conservative bias in accounting practices affects the impact of the growth in short-term and long-term net operating assets differently. This result indicates that the accrual anomaly is not just another representation of the growth anomaly, as FWY suggest. Finally, we employ the Mishkin (1983) model to assess the efficiency of different exchanges around the world in impounding the relative persistence of growth in net long-term operating assets and accruals. We extend internationally the FWY findings of market inefficiency with regard to the impounding in stock prices information conveyed by investments in short-term and long-term net operating assets.

The next section describes the background for this study and the development of our index. The following sections present our hypotheses, the methodology used, and the research design. The empirical results are then discussed, followed by a conclusion.

\section{BACKGROUND AND DEVELOPMENT OF THE INDEX}

While accounting research has repeatedly established that the level of a firm's profitability in one year persists, to a great extent, into the subsequent year (e.g., Nichols and Wahlen 2004), Ohlson (1995) and Feltham and Ohlson (1995) show that future profitability is also related to the growth in net operating assets. Using thirty years of US data, FWY (2003) demonstrate that after controlling for current profitability, growth in net operating assets has a negative effect on the following year's profitability. They provide two possible explanations for the negative effect of this growth: (1) diminishing marginal returns on investments and (2) conservative bias in accounting procedures and practices which results in investments appearing relatively less profitable in early years and more profitable in later years. FWY show that both the short-term and long-term components of growth in net operating assets-accruals and growth in long-term net operating assets-have negative persistence, but that investors overvalue the importance of both of these components in pricing US stocks.

Variation in accounting practices among countries provides an opportunity to test for the contribution of conservative bias as an explanation for the findings of FWY and a means of investigating whether the growth anomaly documented by FWY exists internationally. We do not expect the economic phenomenon of diminishing marginal returns on investments to vary across countries or time periods. On the other hand, cultures and regional accounting standards differ with regard to their level of conservatism. We examine the role of conservatism by determining whether there are differences between countries or within countries over time due to the use of more or less conservative accounting methods for depreciation and amortization and for the expensing of research and development costs.

While accounting policy within a country is established by that country's standards setter, we anticipate that there might be differences in practice by firms listed on different exchanges within a country. Hence, we select only firms listed on the primary exchange in each country. 


\section{Index Development}

As a broad means of categorizing the accrual accounting practices of firms in these countries over time, we calculate an index to measure their relative aggressiveness in allocating the cost of long-term operating assets to expense.

Penman (2004) defines conservatism as a biased application of historical cost accounting characterized by the choice of accounting methods or estimates that keep the book values of net assets relatively low and result in higher charges to income. Not only do these practices yield higher return-on-assets measures in the future due to the reduction of the denominator, but they create unrecorded reserves that can be increased by increasing investment or released by reducing the rate of investment.

Penman and Zhang (2002) show that conservative accounting and changes in investment create income effects that are temporary and are not persistent, although they are valued by the stock market as if they were sustainable. To measure conservatism, they develop a conservatism index based on the estimated reserves created by expensing (rather than capitalizing) research and development costs and advertising costs and by selecting the LIFO method of inventory valuation.

The largest component of accruals is usually the depreciation and amortization expense (e.g., Dechow et al. 1994). Conservatism would suggest the use of accelerated methods of depreciation, while straight-line depreciation would be what Penman (2004) calls a "neutral" accounting choice. While the difference between these two methods would represent an unrecorded reserve as described by Penman and Zhang (2002), they do not use it in developing their conservatism index because of the inability to measure the unrecorded reserves created by using accelerated methods for individual companies. However, we believe that its importance, especially in relation to operating assets, makes it central to assessing the extent of conservative accounting practices from country to country. Moreover, the information regarding the relative amounts allocated to depreciation expense by firms is readily available across countries. Hence, we construct a simple index based on the relationship between the long-term operating assets and the related expenses for depreciation and amortization and for research and development costs (R\&D), as:

Index $=\underline{\text { Depreciation/amortization expense }+\mathrm{R} \& D \text { expense }}$

Property, plant and equipment + Intangible assets

This index, then, is the ratio of the current year's depreciation and amortization expense plus research and development expense to the sum of the cost of the property, plant and equipment and the book value of intangible assets. Unfortunately, the original cost of intangible assets is not readily available, so the denominator of this index includes intangible assets at their carrying value.

There are a number of papers that develop measures of conservatism (e.g., Basu 1997; Penman and Zhang 2002, Easton and Pae 2004; Beaver and Ryan 2005; Monahan 2005). In contrast, our index provides a relative measure of how aggressively firms in different countries allocate the costs of their long-term investments to income due to accounting choices, the cost structure of their industries, or the application of required accounting standards for their locales.

We have not included impairment losses in the numerator of our conservatism index, even though the recording of impairment losses is an accounting choice pertaining to long-term assets. However, we know that losses due to impairment of assets did not gain global attention in accounting standards or practice until the post2000 period. Indeed, in the pre-2000 period, impairments were never recorded by non-US firms included in our study and were recorded rarely by US firms. Impairment accounting only began to be applied in Japan in 2004, and then it was only applied on a voluntary basis until 2006. A small number of impairment losses were recorded in France and Germany after 2000, but they are still recorded less often than in the common-law countries (except Canada, where they are negligible). 
The focus on asset impairments resulted from the discussions of business combinations and recording intangible assets with indefinite lives in the US and by the International Accounting Standards Board (IASB), and it heightened in 2000 and shortly thereafter. Hence, because we know that including impairment losses would have a directional impact on the index in the post-2000 period, particularly for the US, we limit the metric to the more conventional measures to observe whether there is a change in practice where there is not a change in the standard. With the growing tendency in the US toward early loss recognition (see, for instance, Ball et al. 2000, Givoly and Hayn 2000, 2002), we would expect to observe an increase in the conservatism index for the US; instead, there is a slight decrease which, along with the omission of impairment losses, may be partly attributable to the cessation of goodwill amortization in 2001.

Although the calculation of this cost-allocation index is limited to depreciation, amortization and research and development expense accounting, we expect to find differences across countries and over time. Both Ball et al. (2000) and Fulkerson et al. (2002), in reviewing the elements of international diversity, conclude that the common/code-law classification scheme parsimoniously captures the international differences likely to influence the adoption and implementation of accrual principles and practices. Accordingly, we expect that the code-law countries will have higher indices, at least in the earlier years, due to their creditor orientation. Ballweiser (2001) says of German accounting, for instance: "The strong influence of the prudence principle looks to the interests of creditors by minimizing profits rather than making good information available" (p. 1223). However, as this focus changes over the 1996 through 2003 period, with the developing global financial markets and the growing convergence of accounting standards, we expect to find some convergence in the countries' indices.

Table 1: Measures of the Conservatism Index by Country and Exchange

\begin{tabular}{lcccccc}
\hline & \multicolumn{2}{c}{ France } & \multicolumn{2}{c}{ Germany } & \multicolumn{2}{c}{ UK } \\
& mean & median & mean & median & mean & median \\
\hline 1996 & .114 & .080 & .091 & .076 & .12 & .075 \\
1997 & .114 & .083 & .104 & .078 & .194 & .078 \\
1998 & .111 & .080 & .109 & .080 & .297 & .08 \\
1999 & .113 & .076 & .115 & .083 & .224 & .081 \\
2000 & .143 & .086 & .177 & .097 & .312 & .079 \\
2001 & .149 & .088 & .210 & .098 & .271 & .088 \\
2002 & .227 & .097 & .208 & .111 & .266 & .092 \\
2003 & .186 & .094 & .208 & .110 & & .087
\end{tabular}

\begin{tabular}{lcccccc} 
& \multicolumn{2}{c}{ US } & \multicolumn{2}{c}{ Canada } & \multicolumn{2}{c}{ Japan } \\
& mean & median & mean & median & .053 & .047 \\
1996 & .113 & .077 & .119 & .059 & .052 & .046 \\
1997 & .109 & .077 & .137 & .060 & .050 & .044 \\
1998 & .108 & .074 & .189 & .063 & .053 & .042 \\
1999 & .108 & .073 & .232 & .065 & .081 & .062 \\
2000 & .105 & .075 & .264 & .069 & .080 & .061 \\
2001 & .105 & .074 & .270 & .073 & .085 & .060 \\
2002 & .095 & .066 & .263 & .065 & .091 & .058 \\
2003 & .088 & .064 & .221 & .069 & & \\
\hline
\end{tabular}

Conservatism Index $=$ Depreciation/amortization expense $+\mathrm{R} \& D$ expense

Property, plant and equipment + Intangible assets

The means and medians of the computed conservatism indices are shown in Table 1 by country and by year. For almost every year, the highest mean and median of the index are for France and Germany. Moreover, the medians for the eight years of indices for France and Germany do not test as significantly different from each other, while significant differences are found between all the other countries. Based on the medians presented in Table I, the conservatism index rankings for the six countries are as follows:

France $=$ Germany $>$ UK $>$ US $>$ Canada $>$ Japan 
Except for Japan, the rankings are consistent with expectations. The countries with the highest median indices, France and Germany, both have a code-law tradition. The next three, the UK, the US and Canada, are common-law countries; their accounting systems all developed from Anglo-Saxon roots. The indices for these three countries are lower than those of France and Germany, but greater than the one for Japan, which has the lowest index. Since Japan has a code law system, many international accounting research studies group it with the continental European countries. Yet, for the purposes of this study, its index indicates that it should be classified separately. While we had expected Japan to be more closely aligned with the other code-law countries, the fact that its index is the lowest may result from the country's economic distress during the later 1990s or it may be due to accounting, corporate governance structures or cultural practices that stem from factors other than their code-law heritage. Differences that support considering Japan on its own and not with France and Germany are its geographic location, its distinctly different cultural traditions, and an accounting system that was influenced by the United States during the aftermath of World War II.

More striking than the differences between countries, however, is the change over time in the indices for most of the countries. For every country except the US, we observe that the indices increase over the years, with a considerable jump around the year 2000. While this change is undoubtedly related to a number of economic and commercial circumstances, including the $\mathrm{Y} 2 \mathrm{~K}$ acceleration and deceleration of investment, we attribute a significant part of it to the acceptance by the International Organization of Securities Commissions (IOSCO) of the "core" international accounting standards and the growing movement toward adoption of, or convergence with, those standards. As part of the G4+1 group, which disbanded in 2001 with the formation of the IASB, the three commonlaw countries were active in discussions about accounting convergence for several years prior to 2000 . In early 2000, Sir Sydney Lipworth, chairman of the UK's Financial Reporting Council, was quoted as saying it is "a time when developments at home or internationally could involve fundamental changes in the framework for financial reporting" (www.frc.org.uk/press/pub0166.html). In June 2000, the European Commission stated its intention to submit legislation to the European Parliament that would make it mandatory for all listed companies in the European Union to prepare consolidated financial statements in accordance with International Accounting Standards (IAS) (www.iasplus.com/restruct/euro2001.htm). At the same time, the constraint that financial reporting conform to tax regulations in many code-law countries was lifted, and public firms were permitted to file consolidated annual reports using different accounting principles than those used in the individual accounts required for local filings (Sellhorn and Gornik-Tomasjewski 2006). This change may have influenced the indices for France and Germany at this time. Concurrently, Japanese accounting went through a series of reforms that accelerated during the later 1990s due to local economic distress, ultimately resulting in what is referred to as the "Accounting Big Bang" in the country, with changes in accounting for consolidations, tax effects, pensions, financial instruments and impairments (www.iasplus.com/resource/0406ifrs japangaap.pdf). It is noteworthy that all six of the countries in this study have liaison representatives on the IASB, which was formed in April 2001.

Although the exact timing of the shift in accounting practice reflected in our index differs slightly across these countries, we have elected to partition the data uniformly, using the year 2000 as the cut-off point. T-tests comparing the means and the medians for the pre-2000 and post-2000 (including 2000) groups for each country indicate statistically significant differences at the level of $\mathrm{p}<.05$ between the indices of the two periods for each country except the US. Hence, we conclude that, in addition to statistically significant differences between countries, there are measurably different levels of conservatism in accounting practices within most countries for the two periods, which guides us to separate the regression results for each country into pre-2000 and post-2000 (including 2000) sets.

\section{HYPOTHESES DEVELOPMENT}

While we do not expect to observe significant differences in diminishing marginal returns across countries or time periods, the significantly different cost-allocation indices that we compute indicate that there may be differences due to the impact of the level of conservative bias of the accounting practices of the firms located in different locales. If the persistence of the growth in net operating assets is found to be significantly negative for a country where companies tend to use more conservative accounting methods and not significantly different from zero for a country where companies tend to use less conservative accounting methods, the level of conservatism could be an explanatory factor. Accordingly, the first part of our first hypothesis is: 
$\mathbf{H}_{1 \mathrm{~A}}$ : The more conservative a country's accounting practices, the more likely the growth of net operating assets will have a negative effect on the following year's profitability, after controlling for current profitability.

As our index indicates, the level of conservative bias varies not only among countries, but across time for individual countries. If the persistence of the growth in net operating assets is found to be significantly negative during a time period when the companies in a country use more conservative accounting practices, but is not significantly negative during a time period when their accounting is less conservative, then the level of conservatism could be an explanatory factor. Hence, the second part of the first hypothesis is:

$\mathbf{H}_{1 \mathbf{B}}$ : If accounting practices within a country become more (less) conservative over time, the growth of net operating assets is more (less) likely to have a significantly negative effect on the following year's profitability, after controlling for current profitability.

FWY disaggregate growth in net operating assets into its long-term and short-term components, growth in net long-term operating assets and accruals, to test whether the two components represent dual manifestations of the same growth anomaly. To support their commonality, they show that growth in net long-term operating assets and accruals have statistically similar negative effects on the following year's profitability. FWY recognize two explanations for the negative persistence of the composite growth in net operating assets - diminishing marginal returns on investments and conservative bias in accounting practices. We suggest that, while both explanations apply to both components of the growth in net operating assets in different countries, the two components may be impacted differently by the relative conservatism in the countries' modes of accounting. If there is a statistically significant difference between the negative persistence of accruals and the negative effect on future profitability of the growth in net long-term operating assets that varies across countries with the relative conservatism of their accounting practices, it would indicate that they are not, in fact, aspects of the same phenomenon. The first part of our second hypothesis is:

$\mathbf{H}_{2 \mathrm{~A}}$ : After controlling for current profitability, the relative effects of the two components of a company's growth in net operating assets - accruals and growth in net long-term operating assets - on the following year's profitability, are affected by the conservative bias of a country's accounting practices.

If the growth in net long-term operating assets and accruals are manifestations of the growth anomaly, a within-country change in accounting bias over time should impact both components in the same way, without changing their relative negative impact on next year's profitability. The second part of our second hypothesis is:

$\mathbf{H}_{2 \mathrm{~B}}$ : After controlling for current profitability, the relative effects of the two components of a company's growth in net operating assets - accruals and growth in net long-term operating assets - on the following year's profitability, are affected by changes in the conservative bias of a country's accounting practices.

We expect that the negative persistence of accruals may be statistically distinguishable from the negative effect of the growth in net long-term operating assets within a country as the accounting bias becomes more conservative.

Prior research (e.g., Sloan 1996) has demonstrated that accruals are overvalued by investors, and FWY demonstrate that information conveyed by both the persistence of accruals and the growth in long-term net operating assets are incorrectly impounded in market prices. We expect to find similar market inefficiencies with regard to the market valuations of accruals and the growth in long-term net operating assets, especially as regards investor perception of the accounting regime's accrual process. Hence, we expect to observe mispricing of accruals and the growth in long-term net operating assets. Our final hypothesis is:

$\mathbf{H}_{3}$ : $\quad$ Neither the persistence of accruals, nor the persistence of the growth of long-term operating assets, will be accurately reflected in market pricing, after controlling for current profitability.

FWY cite their finding of equivalent US market mispricing of accruals and growth in long-term net operating assets as evidence that these two components of the growth in net operating assets are part of the same 
growth anomaly. Lack of the same equivalence internationally would provide evidence that the accruals anomaly (Sloan 1996) is distinct from the growth anomaly demonstrated by FWY.

\section{METHODOLOGY}

\section{Sample Selection}

The sample is drawn from the Thomson Financial international database, Worldscope. Financial reports filed through 2004 are included in the version of the database we used for this study. We selected our sample from the reporting years 1995 through 2004. Many countries provided scant data prior to 1995, so we began with this year to ensure adequate coverage.

We used data as reported in the local currency on local exchanges. We specified one exchange (the primary one) for each country, which we determined to be: Canada, Toronto Exchange; France, Paris Exchange; Germany, Frankfurt Exchange; Japan, Tokyo Exchange; the United Kingdom, London Exchange; the US, the New York Stock Exchange (NYSE). By eliminating the possibility of variation between exchanges within a country, we can better focus on the differences between countries in the accrual practices and market pricing of earnings components.

We selected firms classified as manufacturing, retail, service, and transportation, omitting financial services and other specialized industries. After eliminating firms missing key data items, we trimmed less than $1 \%$ of the companies for each country due to extreme values.

\section{Variables}

We follow the methods used by FWY to determine the variables. For each firm selected, we use the current and prior year data to compute differences in receivables, inventory, prepaid and other current assets, accounts payable and other current liabilities, from which we determine the change in working capital. The change in working capital is combined with depreciation and amortization expense for the current year (one data item in Worldscope) to arrive at accruals. The change in working capital plus the differences between the current and prior year's plant assets, intangibles, other long-term assets and liabilities (i.e., the long-term operating assets) yield the growth in net operating assets. (Note that cash and all financing assets and liabilities are excluded from the calculation of operating assets.)

The variables used in the analysis that follows include:

\begin{tabular}{|c|c|c|}
\hline$R O A_{i t+1}$ & $=$ & Next year's operating income divided by average total assets; \\
\hline$R O A_{i t}$ & $=$ & This year's operating income divided by average total assets; \\
\hline $\mathrm{GrNOA}_{i t}$ & $=$ & The growth (annual change) in net operating assets; \\
\hline GrLTNOA $A_{i t}$ & $=$ & The growth (annual change) in net long-term operating assets; \\
\hline$A C C_{i, t}$ & $=$ & $\begin{array}{l}\text { Accruals, computed as the growth (annual change) in working capital accounts, minus } \\
\text { current-period depreciation and amortization expense; }\end{array}$ \\
\hline$A R_{i t+1}$ & $=$ & $\begin{array}{l}\text { Abnormal returns, computed as the difference between the reported return and the median of } \\
\text { reported returns for the quintile of firms of the same size (determined by average total } \\
\text { assets). }\end{array}$ \\
\hline
\end{tabular}

Because the regressions use the profitability and return for a year forward, as well as the change from the year prior, the ten years of data retrieved for each firm result in eight firm-years of data. Descriptive statistics for these variables by country and by period are shown in Table 2 . 
Table 2: Descriptive Statistics

France Pre-2000

\begin{tabular}{lllllll}
\hline & ROA1 $_{\mathbf{t + 1}}$ & $\mathbf{R O A 1}_{\mathbf{t}}$ & $\mathbf{A C C}_{\mathbf{t}}$ & $\mathbf{G r N O A}_{\mathbf{t}}$ & $\mathbf{G r L T N O A}_{\mathbf{t}}$ & $\mathbf{A R}_{\mathbf{t + 1}}$ \\
\hline Mean & 0.073 & 0.083 & $(0.041)$ & 0.060 & 0.101 & 0.129 \\
Median & 0.077 & 0.082 & $(0.044)$ & 0.039 & 0.075 & 0.000 \\
St. Dev. & 0.114 & 0.102 & 0.116 & 0.152 & 0.109 & 0.689 \\
$\begin{array}{l}\text { France Post-2000 } \\
\text { Mean }\end{array}$ & 0.037 & 0.048 & $(0.043)$ & $(0.079)$ & $(0.036)$ & 0.044 \\
Median & 0.056 & 0.060 & $(0.039)$ & $(0.021)$ & 0.024 & 0.000 \\
St. Dev. & 0.137 & 0.137 & 0.133 & 0.285 & 0.247 & 0.498 \\
\hline
\end{tabular}

Germany Pre-2000

\begin{tabular}{lllllll}
\hline & ROA1 $_{\mathbf{t + 1}}$ & $\mathbf{R O A 1}_{\mathbf{t}}$ & $\mathbf{A C C}_{\mathbf{t}}$ & $\mathbf{G r N O A}_{\mathbf{t}}$ & $\mathbf{G r L T N O A}_{\mathbf{t}}$ & $\mathbf{A R}_{\mathbf{t + 1}}$ \\
\hline Mean & 0.050 & 0.064 & $(0.025)$ & 0.083 & 0.109 & 0.062 \\
Median & 0.069 & 0.073 & $(0.037)$ & 0.045 & 0.078 & 0.000 \\
St. Dev. & 0.171 & 0.124 & 0.144 & 0.216 & 0.157 & 0.467 \\
Germany Post-2000 & & & & & 0.096 & 0.095 \\
Mean & $(0.019)$ & $(0.016)$ & $(0.065)$ & 0.031 & 0.062 & 0.000 \\
Median & 0.037 & 0.038 & $(0.065)$ & 0.007 & 0.213 & 0.588 \\
St. Dev. & 0.210 & 0.215 & 0.187 & 0.279 & & \\
\hline
\end{tabular}

UK Pre-2000

\begin{tabular}{lllllll}
\hline & ROA1 $_{\mathbf{t + 1}}$ & $\mathbf{R O A 1}_{\mathbf{t}}$ & $\mathbf{A C C}_{\mathbf{t}}$ & $\mathbf{G r N O A}_{\mathbf{t}}$ & $\mathbf{G r L T N O A}_{\mathbf{t}}$ & $\mathbf{A R}_{\mathbf{t + 1}}$ \\
\hline Mean & 0.072 & 0.082 & $(0.032)$ & 0.075 & 0.106 & 0.145 \\
Median & 0.102 & 0.109 & $(0.032)$ & 0.047 & 0.067 & 0.000 \\
St. Dev. & 0.183 & 0.187 & 0.119 & 0.202 & 0.177 & 0.801 \\
UK Post-2000 & & & & & & 0.099 \\
Mean & $(0.028)$ & $(0.025)$ & $(0.056)$ & 0.043 & 0.099 & 0.000 \\
Median & 0.047 & 0.051 & $(0.048)$ & 0.015 & 0.054 & 0.658 \\
St. Dev. & 0.257 & 0.262 & 0.119 & 0.255 & 0.229 & \\
\hline
\end{tabular}

US Pre-2000

\begin{tabular}{lllllll}
\hline & ROA1 $_{\mathbf{t + 1}}$ & ROA1 $_{\mathbf{t}}$ & $\mathbf{A C C}_{\mathbf{t}}$ & $\mathbf{G r N O A}_{\mathbf{t}}$ & $\mathbf{G r L T N O A}_{\mathbf{t}}$ & $\mathbf{A R}_{\mathbf{t + 1}}$ \\
\hline Mean & 0.113 & 0.115 & $(0.034)$ & 0.107 & 0.141 & 0.094 \\
Median & 0.111 & 0.113 & $(0.040)$ & 0.063 & 0.094 & 0.000 \\
St. Dev. & 0.112 & 0.112 & 0.087 & 0.217 & 0.193 & 0.557 \\
US Post-2000 & & & & & & 0.070 \\
Mean & 0.087 & 0.093 & $(0.046)$ & 0.051 & 0.097 & 0.000 \\
Median & 0.085 & 0.090 & $(0.046)$ & 0.024 & 0.063 & 0.488 \\
St. Dev. & 0.105 & 0.108 & 0.085 & 0.507 & 0.500 & \\
\hline
\end{tabular}

Canada Pre-2000

\begin{tabular}{|c|c|c|c|c|c|c|}
\hline & $\operatorname{ROA1}_{t+1}$ & ROA1 $_{t}$ & $\mathrm{ACC}_{\mathrm{t}}$ & GrNOA $_{t}$ & GrLTNOA $_{t}$ & $\mathbf{A} \mathbf{R}_{\mathbf{t + 1}}$ \\
\hline Mean & 0.017 & $(0.017)$ & $(0.021)$ & 0.248 & 0.269 & 0.721 \\
\hline Median & 0.073 & 0.073 & $(0.038)$ & 0.087 & 0.121 & 0.000 \\
\hline St. Dev. & 0.237 & 0.451 & 0.207 & 0.495 & 0.443 & 14.936 \\
\hline \multicolumn{7}{|c|}{ Canada Post-2000 } \\
\hline Mean & $(0.038)$ & $(0.040)$ & $(0.052)$ & 0.110 & 0.162 & 0.160 \\
\hline Median & 0.033 & 0.035 & $(0.045)$ & 0.042 & 0.074 & $(0.002)$ \\
\hline St. Dev. & 0.275 & 0.329 & 0.140 & 0.376 & 0.355 & 0.841 \\
\hline \multicolumn{7}{|c|}{ Japan Pre-2000 } \\
\hline & $\operatorname{ROA1}_{t+1}$ & ROA1 $_{t}$ & $\mathrm{ACC}_{\mathrm{t}}$ & $\mathrm{GrNOA}_{\mathrm{t}}$ & GrLTNOA $_{t}$ & $\mathbf{A} \mathbf{R}_{t+1}$ \\
\hline Mean & 0.035 & 0.040 & $(0.020)$ & 0.015 & 0.036 & 0.094 \\
\hline Median & 0.032 & 0.035 & $(0.019)$ & 0.011 & 0.027 & 0.000 \\
\hline St. Dev. & 0.050 & 0.046 & 0.048 & 0.057 & 0.046 & 0.472 \\
\hline
\end{tabular}




\begin{tabular}{|c|c|c|c|c|c|c|c|}
\hline \multicolumn{8}{|c|}{ Japan Post-2000 } \\
\hline Mean & & 0.036 & 0.033 & $(0.031)$ & 0.008 & 0.039 & 0.074 \\
\hline Median & & 0.032 & 0.030 & $(0.032)$ & 0.003 & 0.027 & $(0.001)$ \\
\hline St. Dev. & & 0.065 & 0.068 & 0.065 & 0.093 & 0.077 & 0.546 \\
\hline$R O A_{i t+1}$ & $=$ & Next & rating in & led by av & l assets & & \\
\hline$R O A_{i t}$ & $=$ & This & ating in & led by ave & 1 assets & & \\
\hline $\operatorname{GrNOA}_{i t}$ & $=$ & The & iual cha & operatin & & & \\
\hline $\operatorname{GrLTNOA}_{i t}$ & $=$ & The & iual cha & long-terı & ig asset & & \\
\hline$A C C_{i, t}$ & $=$ & $\begin{array}{l}\text { Accr } \\
\text { depre }\end{array}$ & $\begin{array}{l}\text { uted as } \\
1 \text { amorti }\end{array}$ & $\begin{array}{l}\text { (annual } \\
\text { ense; }\end{array}$ & in worl & accou & current-period \\
\hline$A R_{i t+1}$ & $=$ & $\begin{array}{l}\text { Abnc } \\
\text { repor }\end{array}$ & $\begin{array}{l}\text { s, coml } \\
\text { for the }\end{array}$ & $\begin{array}{l}\text { differen } \\
\text { firms of }\end{array}$ & $\begin{array}{l}\text { n the re } \\
\text { ize (de }\end{array}$ & $\begin{array}{l}\mathrm{rn} \text { and } \mathrm{t} \\
\text { averag }\end{array}$ & $\begin{array}{l}\text { of } \\
\text { ts). }\end{array}$ \\
\hline
\end{tabular}

\section{Tests}

We first perform the basic test to show that, for our sample of countries in the two time periods, the level of profitability in one year persists to a great extent into the subsequent year, using the equation:

$R O A_{i t+l}=\alpha+\beta R O A_{i t}+\varepsilon_{i t}$

where $R O A$ represents firm $(i)$ profitability for the current year $(t)$ and next year $(t+1)$.

To test our first hypothesis, we add the current year's growth in net operating assets (GrNOA) to the equation, in the manner of Ohlson (1995), to assess whether the current year's growth in net operating assets $(\mathrm{GrNOA})$ is also a persistent and negative component of profitability, as:

$R O A_{i t+1}=a+\beta_{1} G r N O A_{i t}+\beta_{2} R O A_{i t}+\varepsilon_{i t}$

A finding that the persistence of the growth in net operating assets is significantly more negative for countries with a high cost-allocation index would suggest that conservative bias is relevant in explaining the growth anomaly, supporting $\mathrm{H}_{1 \mathrm{a}}$, and a finding that the negativity changes with increases in the index over time would support $\mathrm{H}_{1 \mathrm{~b}}$.

Our second hypothesis indicates that we expect variation in accounting practices across countries to impact the change in net short-term operating assets (accruals) differently than that of net long-term operating assets. Following FWY, we modify equation [2] by disaggregating the current year's growth in net operating assets into its long-term and short-term components, growth in long-term net operating assets (GrLTNOA) and accruals (ACC), as:

$R O A_{i t+1}=a+\beta_{1} G r L T N O A_{i t}+\beta_{2} A C C_{i, t}+\beta_{3} R O A_{i, t}+\varepsilon_{i t}$

A finding that the significant negative persistence of accruals differs from that of the growth in long-term net operating assets for countries with a high cost-allocation index would support $\mathrm{H}_{2 \mathrm{a}}$ and a finding that the relative impact changes with increases in the index over time would support $\mathrm{H}_{2 \mathrm{~b}}$, both suggesting that conservative bias is relatively more important than diminishing marginal returns in explaining the growth anomaly. Significant differences between the coefficients for the two components of the growth in net operating assets would also indicate that internationally, they are not simply two parts of the growth anomaly.

Finally, we use the set of simultaneous equations developed by Miskin (1983) to test whether investors correctly value the relative persistence of growth in net long-term operating assets (GrLTNOA) and accruals (ACC), as:

$$
\begin{aligned}
& R O A_{i t+1}=a+\beta_{1} \text { GrLTNOA }_{i t}+\beta_{2} \text { ACC }_{i, t}+\beta_{3} R O A_{i, t}+\varepsilon_{i t} \\
& A R_{i t+1}=a_{2}+\beta_{4}\left(\text { ROA }_{i t+1}-a-\beta_{5} \text { GrLTNOA }_{i t}+\beta_{6} A C C_{i, t}+\beta_{7} \text { ROA }_{i, t}\right)+\varepsilon_{i t}
\end{aligned}
$$


where $A R$ represents next year's abnormal returns for the firm. If investors value the persistence correctly, the coefficients for growth in net long-term operating assets $\left(\beta_{1}\right.$ and $\left.\beta_{5}\right)$ and for accruals $\left(\beta_{2}\right.$ and $\left.\beta_{6}\right)$ will not be statistically different. We expect that, like FWY and previous researchers (Sloan 1996) for US firms, we will find that investors are unable to correctly value this persistence, supporting our third hypothesis.

\section{RESULTS}

We first perform a benchmark test of the persistence of earnings. Panel A of Table 3, the regression of $\mathrm{ROA}_{t+1}$ on $\mathrm{ROA}_{\mathrm{t}}$, establishes that for all of the countries in this study there is a significant, positive year-to-year relationship for the earnings metric. Although the magnitude of the coefficient and the adjusted $\mathrm{R}^{2}$ for the model differs from country to country and from the pre-2000 period to the post-2000 period, the coefficient for $\mathrm{ROA}_{\mathrm{t}}$ is always positive and significant, consistent with prior research (e.g., Sloan 1996; FWY 2003). In Table 3 and the remaining tables, the countries are listed in the order of their median cost-allocation indices, from highest to lowestthat is, with France and Germany first and Japan last.

Table 3: Persistence of Earnings and Growth in Net Operating Assets

Next Year's ROA Regressed on This Year's ROA, This Year's ROA and Growth in Net Operating Assets

Panel A: Basic model: $R O A_{i t+1}=a+\beta R O A_{i t}+\varepsilon_{i t}$

Panel B: Expanded Model: $R O A_{i t+1}=a+\beta_{1} G r N O A_{i t}+\beta_{2} R O A_{i t}+\varepsilon_{i t}$

\section{Panel A:}

\begin{tabular}{|c|c|c|c|c|c|c|c|c|}
\hline & $N$ & $a$ & $\beta$ & Adj. $\mathrm{R}^{2}$ & $a$ & $\beta_{1}$ & $\beta_{2}$ & Adj. $R^{2}$ \\
\hline \multicolumn{9}{|l|}{ France } \\
\hline Pre-2000 & 1319 & $.014 * *$ & $.714 * *$ & .411 & $.016^{* *}$ & $-.072 * *$ & $.737 * *$ & .420 \\
\hline Post-2000 & 1953 & $.005^{*}$ & $.659 * *$ & .430 & .002 & $-.039 * *$ & $.676^{* *}$ & .436 \\
\hline \multicolumn{9}{|l|}{ Germany } \\
\hline Pre-2000 & 1107 & .005 & $.710 * *$ & .266 & $.018 * *$ & $-.210 * *$ & $.766^{* *}$ & .335 \\
\hline Post-2000 & 1883 & $-.011 * *$ & $.453 * *$ & .216 & -.056 & $-.161 * *$ & $.511 * *$ & .258 \\
\hline \multicolumn{9}{|l|}{ UK } \\
\hline Pre-2000 & 2423 & $.019 * *$ & $.644 * *$ & .435 & $.024 * *$ & $-.086 * *$ & $.660 * *$ & .443 \\
\hline Post-2000 & 3443 & $-.012 * *$ & $.623 * *$ & .402 & -.005 & $-.147 * *$ & $.659 * *$ & .422 \\
\hline \multicolumn{9}{|l|}{ US } \\
\hline Pre-2000 & 3864 & $.047 * *$ & $.573 * *$ & .331 & $.050^{* * *}$ & $-.035 * *$ & $.577 * *$ & .336 \\
\hline Post-2000 & 4007 & $.030 * *$ & $.617 * *$ & .404 & $.030 * *$ & $-.015 * *$ & $.627 * *$ & .409 \\
\hline \multicolumn{9}{|l|}{ Canada } \\
\hline Pre-2000 & 1113 & $.021 * *$ & $.243 * *$ & .212 & $.018 *$ & .014 & $.242 * *$ & .212 \\
\hline Post-2000 & 2364 & $-.018 * *$ & $.488 * *$ & .340 & $-.015 * *$ & $-.030 *$ & $.492 * *$ & .342 \\
\hline \multicolumn{9}{|l|}{ Japan } \\
\hline Pre-2000 & 6245 & $.004 * *$ & $.785^{* *}$ & .523 & $.004 * *$ & -.008 & $.788 * *$ & .523 \\
\hline Post-2000 & 7256 & $.017 * *$ & $.554 * *$ & .328 & $.017 * *$ & $-.045 * *$ & $.568 * *$ & .332 \\
\hline
\end{tabular}

$* * /(*)$ Indicates significance for $\mathrm{p}$-values $<.01 /(<.10)$.

$\mathrm{ROA}=$ return on assets, defined as operating income divided by average total assets

GrNOA = growth in net operating assets, defined as the growth (annual change) in net operating assets (working capital accounts, plant assets, intangibles, other long-term non-financial assets and liabilities)

The results of the regressions of next year's profitability $\mathrm{ROA}_{\mathrm{t}+1}$ on the growth in net operating assets $\mathrm{GrNOA}_{t}$, controlling for current profitability ROA ${ }_{t}$, for the two time periods, are presented in Table 3, Panel B. These results provide information regarding the two parts of our first hypothesis. For the post-2000 period, the coefficients for $\mathrm{GrNOA}_{t}$ for all six countries are negative and significant. This result is consistent with FWY, providing international evidence that, from 2000 on, investments in net operating assets depress the following year's earnings. On the other hand, for the pre-2000 period for both Japan and Canada the coefficients for GrNOA $\mathrm{t}_{\mathrm{t}}$ are insignificant. Although Japan and Canada are generally not classified together in international accounting groupings of countries, since they have different legal systems, accounting heritages and corporate financing structures, in this study they have the lowest cost allocation indices. For the four countries with higher indices, the coefficients for $\mathrm{GrNOA}_{t}$ are significantly negative. The fact that for the pre-2000 time period, the coefficients for $\mathrm{GrNOA}_{t}$ for the 
four countries with the more conservative accounting practices are negative and significant, but they are not for the two countries with less conservative accounting practices, supports the first part of the first hypothesis. Thus, we find that during the pre-2000 period, the investment in net operating assets in countries where the accounting is more conservative, as measured by our index, is more likely to have a negative impact on the following year's ROA than in a country where the accounting is not as conservative.

These same results for the two countries with the lowest conservatism indices, Canada and Japan, provide evidence that when accounting becomes more conservative, investments in net operating assets will be more likely to have a negative impact on the following year's profitability than when it was not as conservative. For these two countries, the coefficients for $\mathrm{GrNOA}_{t}$ are insignificant in the pre-2000 period, but are significant and negative in the post-2000 period. Given that the cost-allocation indices for these two countries are significantly greater during the second period than the first, these results support the second part of the first hypothesis, that if a country's accounting practices become more conservative over time, the growth of net operating assets is more likely to have a significantly negative effect on the following year's profitability, after controlling for current profitability.

These results with regard to our hypotheses $\mathrm{H}_{1 \mathrm{a}}$ and $\mathrm{H}_{1 \mathrm{~b}}$ demonstrate that the conservative bias explanation put forth by FWY for the growth in net operating assets anomaly is an explanatory factor internationally when a country's accounting practices are at a sufficiently conservative level, but that the negative relationship between investment and future earnings is not significant when accounting conservatism is low.

Table 4: Disaggregated Persistence of Earnings Model

Next Year's ROA Regressed on This Year's ROA and Growth in Net Operating Assets Disaggregated into Growth in Long-Term Operating Assets and Accruals

\begin{tabular}{|c|c|c|c|c|c|c|c|}
\hline & $N$ & $a$ & $\beta_{1}$ & $\beta_{2}$ & $\beta_{3}$ & Adj. $R^{2}$ & $\beta_{1}=\beta_{2}$ \\
\hline \multicolumn{8}{|l|}{ France } \\
\hline Pre-2000 & 1319 & $.013 * *$ & $-.050 *$ & $-.092 * *$ & $.739 * *$ & .420 & \multirow{2}{*}{$\begin{array}{l}\chi^{2}=2.135 \\
\chi^{2}=1.828\end{array}$} \\
\hline Post-2000 & 1953 & .000 & $-.033 * *$ & $-.062 * *$ & $.685^{* *}$ & .436 & \\
\hline \multicolumn{8}{|l|}{ Germany } \\
\hline Pre-2000 & 1107 & $.023 * *$ & $-.239 * *$ & $-.176^{* *}$ & $.764 * *$ & .336 & \multirow{2}{*}{$\begin{array}{l}\chi_{2}^{2}=2.57 \\
x^{2}=4.03 *\end{array}$} \\
\hline Post-2000 & 1883 & -.001 & $-.185 * *$ & $-.126 * *$ & $.504 * *$ & .259 & \\
\hline \multicolumn{8}{|l|}{ UK } \\
\hline Pre-2000 & 2423 & $.024 * *$ & $-.084 * *$ & $-.084 * *$ & $.660 * *$ & .443 & \multirow{2}{*}{$\begin{array}{l}\chi_{2}^{2}=0.015 \\
\chi^{2}=0.074\end{array}$} \\
\hline Post-2000 & 3443 & -.005 & $-.146 * *$ & $-.154 * *$ & $.660 * *$ & .422 & \\
\hline \multicolumn{8}{|l|}{ US } \\
\hline Pre-2000 & 3864 & $.050 * *$ & $-.035 * *$ & $-.034 *$ & $.576^{* *}$ & .335 & \multirow{2}{*}{$\begin{array}{l}\chi_{2}^{2}=.002 \\
\chi^{2}=3.88 *\end{array}$} \\
\hline Post-2000 & 4007 & $.028 * *$ & $-.014 * *$ & $-.045^{* *}$ & $.631 * *$ & .410 & \\
\hline \multicolumn{8}{|l|}{ Canada } \\
\hline Pre-2000 & 1113 & $.019 *$ & .011 & .027 & $.239 * *$ & .212 & \multirow{2}{*}{$\begin{array}{l}\chi^{2}=.178 \\
\chi^{2}=7.576^{* *}\end{array}$} \\
\hline Post-2000 & 2364 & $-.021 * *$ & $-.019 * *$ & $-.114 * *$ & $.496^{* *}$ & .344 & \\
\hline \multicolumn{8}{|l|}{ Japan } \\
\hline Pre-2000 & 6245 & $.003 * *$ & .006 & $-.020 *$ & $.787 * *$ & .523 & \multirow{2}{*}{$\begin{array}{l}\chi_{2}^{2}=5.034 * \\
\chi^{2}=19.418^{* *}\end{array}$} \\
\hline Post-2000 & 7256 & $.015 * *$ & $-.024 * *$ & $-076 * *$ & $.569 * *$ & .333 & \\
\hline
\end{tabular}

$* * /(*)$ Indicates significance for $\mathrm{p}$-values $<.01 /(<.10)$.

$\mathrm{ROA}=$ return on assets, defined as operating income divided by average total assets

GrLTNOA = growth in long-term net operating assets, defined as the growth (annual change) in net long-term operating assets (plant assets, intangibles, other long-term non-financial assets and liabilities)

ACC $=$ accruals, defined as the growth (net change) in working capital accounts less current-period depreciation and amortization expense, divided by average total assets

In Table 4, we present the results for the third regression model, in which next year's profitability $\mathrm{ROA}_{t+1}$ is regressed on the disaggregation of growth in net operating assets into its long-term and short-term components, GrLTNOA $_{t}$ and $\mathrm{ACC}_{\mathrm{t}}$, after controlling for current profitability $\mathrm{ROA}_{\mathrm{t}}$. In the right-hand column, we present the results of the test of equality of the coefficients for GrLTNOA $t$ and $\mathrm{ACC}_{t}$ to see whether their effect on next year's 
profitability indicates that they are both reflections of the growth anomaly of the aggregate growth in net operating assets. In the pre-2000 period, our findings are consistent with those of FWY for the four countries having the highest indices-France, Germany, the UK, and the US. The two components of growth in net operating assets are each significant determinants of next year's profitability, and their coefficients are not statistically different. For the two countries having the lowest indices, however, this finding does not hold. For Canada these coefficients are insignificant. For Japan, only the coefficient on accruals, $\mathrm{ACC}_{\mathrm{t}}$, is significant, and it is significantly different from

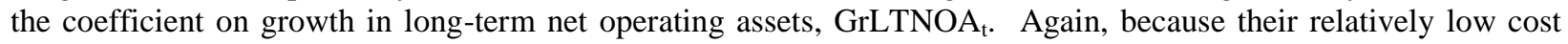
allocation indices appear to be the predominant commonality between Japan and Canada, this finding suggests that conservative bias affects the negative impact of the two components of a company's growth in net operating assets - accruals and growth in long-term net operating assets - on the following year's profitability, indicating support for $\mathrm{H}_{2 \mathrm{~A}}$.

In the post-2000 period, as their conservatism indices change, four of the six countries experience a change in the relative impact of accruals and growth in net long-term operating assets on the following year's profitability. Thus, for only two-France and the UK-do the results remain consistent with those of FWY. For Japan and Canada, both variables are now significant, but the coefficients are significantly different - that is, the coefficient $\beta_{2}$ on accruals, $\mathrm{ACC}_{\mathrm{t}}$, is significantly more negative than the coefficient $\beta_{1}$ on growth in net long-term operating assets, GrLTNOA $_{\mathrm{t}}$. For the US and Germany, the coefficients $\beta_{1}$ and $\beta_{2}$ become significantly different in the post-2000 period. The US, with the third smallest cost allocation index, is similar to Japan and Canada in that the coefficient $\beta_{2}$ on accruals, $\mathrm{ACC}_{\mathrm{t}}$, is now significantly more negative than the coefficient $\beta_{1}$ on growth in net long-term operating assets, GrLTNOA . Interestingly, Germany, which has a high index, is the only country where the coefficient $\beta_{1}$ on growth in net long-term operating assets, GrLTNOA $_{t}$, is more negative than the coefficient $\beta_{2}$ on accruals, $\mathrm{ACC}_{\mathrm{t}}$, and this difference becomes statistically significant in the post-2000 period. These results indicate that changes in the conservative bias of a country's accounting practices has an effect on the relative impact of the two components of a company's growth in net operating assets - accruals and growth in net long-term operating assets - on the following year's profitability, supporting $\mathrm{H}_{2 \mathrm{~B}}$. Moreover, the differential effects of changes in the conservative bias imply that accruals and growth in long-term net operating assets do not always fit under the umbrella of the growth anomaly, as suggested by FWY.

Panel A of Table 5 presents the results of a system of simultaneous equations designed to determine whether market pricing correctly impounds the relative persistence of disaggregated $\mathrm{GrNOA}_{t}-\mathrm{GrLTNOA}_{\mathrm{t}}$ and $\mathrm{ACC}_{\mathrm{t}}$ - controlling for $\mathrm{ROA}_{t}$, as in Mishkin (1983). Wald chi-square tests of equivalence of coefficients are presented in Panel B. If the relative persistence of the variables GrLTNOA,$A_{t} C_{t}$, and $\mathrm{ROA}_{t}$, as demonstrated in the previous test and shown in Table 4, has been correctly incorporated into market price by investors, the coefficients of the variables in the two equations will be similar - that is, they will not be significantly different. The results of the Wald chi-square tests in the first two columns of Table 5, Panel B, showing some statistical differences for five countries, generally supports our third hypothesis: that the persistence of accruals and growth in net long-term operating assets will not be accurately reflected in market prices. Consistent with FWY, the third column shows that the persistence of the control variable $\mathrm{ROA}_{t}$ is not correctly impounded by any of the countries, except for the pre- 2000 period for the UK. We must conclude that, in general, market pricing does not accurately reflect the relative persistence of accruals and growth in net long-term operating assets.

The right-hand column of Panel B, which reports whether the two growth variables are weighted differently from each other in the second equation, provides information pertinent to the FWY growth anomaly. The differential pricing of accruals and growth in long-term net operating assets for most countries, for at least one of the time periods, provides evidence that the accruals anomaly (Sloan 1996) is distinct from the growth anomaly demonstrated by FWY.

Despite the general support of our third hypothesis, for Canada the equality of coefficients for GrLTNOA and $\mathrm{ACC}_{\mathrm{t}}$ should not be rejected, since the persistence of accruals and growth in net long-term operating assets is accurately reflected in market prices for both periods. This result is consistent with other research (Hollister and Shoaf 2007) that reports the finding that market prices on the Canadian exchanges do accurately reflect accounting information for accruals and cash flows. For the post-2000 period, when Canadian accounting is more conservative than pre-2000, the coefficients for the two components of growth in net operating assets are significantly different 
from each other in both equations of the Mishkin model. This result is in direct conflict with the FWY results and provides more evidence to refute their contention that accruals and growth in long-term net operating assets are both part of the same anomaly.

Table 5: Simultaneous Regressions of Persistence and Market Valuation Models

$\operatorname{ROA}_{i t+1}=a+\beta_{1}$ GrLTNOA $_{i t}+\beta_{2} \mathrm{ACC}_{\mathrm{i}, \mathrm{t}}+\beta_{3} \mathbf{R O A}_{\mathrm{i}, \mathrm{t}}+\varepsilon_{\mathrm{it}}$

$\mathrm{AR}_{\mathrm{it}+1}=\mathbf{a}_{2}+\beta_{4}\left(\mathrm{ROA}_{\mathrm{it}+1}-\mathbf{a}-\beta_{5} \mathrm{GrLTNOA}_{\mathrm{it}}+\boldsymbol{\beta}_{6} \mathrm{ACC}_{\mathrm{i}, \mathrm{t}}+\boldsymbol{\beta}_{7} \mathbf{R O A}_{\mathrm{i}, \mathrm{t}}\right)+\varepsilon_{\mathrm{it}}$

Panel A:

\begin{tabular}{|c|c|c|c|c|c|c|c|c|c|}
\hline & $N$ & $\beta_{1}$ & $\beta_{2}$ & $\beta_{3}$ & $\beta_{4}$ & $\beta_{5}$ & $\beta_{6}$ & $\beta_{7}$ & Adj. $R^{2}$ \\
\hline \multicolumn{10}{|l|}{ France } \\
\hline Pre-2000 & 1319 & $-.050 *$ & $-.092 * *$ & $.739 * *$ & $1.790 * *$ & .056 & .029 & -.045 & .089 \\
\hline Post-2000 & 1953 & $-.033 * *$ & $-.062 * *$ & $.685 * *$ & $1.575^{* *}$ & .021 & .005 & $.475^{* *}$ & .113 \\
\hline \multicolumn{10}{|l|}{ Germany } \\
\hline Pre-2000 & 1107 & $-.239 * *$ & $-.176 * *$ & $.764 * *$ & $.804 * *$ & .046 & $.213 *$ & .215 & .071 \\
\hline Post-2000 & 1883 & $-.185 * *$ & $-.126 * *$ & $.504 * *$ & $.769 * *$ & $.337 * *$ & $-.270 * *$ & $.338 * *$ & .081 \\
\hline \multicolumn{10}{|l|}{ UK } \\
\hline Pre-2000 & 2423 & $-.087 * *$ & $-.084 * *$ & $.660 * *$ & $.785 * *$ & $-.501 * *$ & .203 & $.780 * *$ & .023 \\
\hline Post-2000 & 3443 & $-.0146 * *$ & $-.154 * *$ & $.660 * *$ & $.796 * *$ & $.231 * *$ & .118 & $.542 * *$ & .066 \\
\hline \multicolumn{10}{|l|}{ US } \\
\hline Pre-2000 & 3864 & $-.035^{* *}$ & $-.034 *$ & $.576 * *$ & $1.35^{* *}$ & .039 & $-.278 * *$ & $.529 * *$ & .054 \\
\hline Post-2000 & 4007 & $-.014 * *$ & $-.045^{* *}$ & $.631 * *$ & $1.21 * *$ & $-.027 *$ & .036 & $.982 * *$ & .047 \\
\hline \multicolumn{10}{|l|}{ Canada } \\
\hline Pre-2000 & 1113 & .011 & .027 & $.239 * *$ & $5.26^{*}$ & .233 & -.121 &. $.434 *$ & .003 \\
\hline Post-2000 & 2364 & $-.019 *$ & $-.114 * *$ & $.496 * *$ & $.668 * *$ & .080 & -.278 & $.436 * *$ & .032 \\
\hline \multicolumn{10}{|l|}{ Japan } \\
\hline Pre-2000 & 6245 & .006 & $-.020 *$ & $.787 * *$ & $3.360 * *$ & .033 & $.130 * *$ & $.283 * *$ & .086 \\
\hline Post-2000 & 7256 & $-.024 * *$ & $-.076^{* *}$ & $.569 * *$ & $2.218 * *$ & -.002 & $.047 * *$ & $.707 * *$ & .053 \\
\hline \multicolumn{10}{|l|}{ Panel B: } \\
\hline & & $\beta_{1}=\beta_{5}$ & & $\beta_{2}=\beta_{6}$ & & $\beta_{3}=\beta_{7}$ & & $\beta_{5}=\beta_{6}$ & \\
\hline \multicolumn{10}{|l|}{ France } \\
\hline Pre-2000 & & $\chi^{2}=1.21$ & & $\chi^{2}=1.73$ & & $\chi^{2}=32.14 * *$ & & $\chi^{2}=0.05$ & \\
\hline Post-2000 & & $x^{2}=3.52 *$ & & $x^{2}=1.33$ & & $\chi^{2}=12.86 * *$ & & $x^{2}=0.07$ & \\
\hline \multicolumn{10}{|l|}{ Germany } \\
\hline Pre-2000 & & $\chi^{2}=6.10 *$ & & $x^{2}=10.4 * *$ & & $\chi^{2}=39.5 * *$ & & $\chi_{2}^{2}=1.08$ & \\
\hline Post-2000 & & $x^{2}=29.8 * *$ & & $\chi^{2}=1.91$ & & $x^{2}=94.5 * *$ & & $\chi^{2}=15.5^{* *}$ & \\
\hline \multicolumn{10}{|l|}{ UK } \\
\hline Pre-2000 & & $x^{2}=9.64 * *$ & & $\chi^{2}=2.44$ & & $\chi^{2}=1.10$ & & $x^{2}=9.73 * *$ & \\
\hline Post-2000 & & $x^{2}=31.3 * *$ & & $x^{2}=4.79 *$ & & $\chi^{2}=4.24 *$ & & $x^{2}=0.75$ & \\
\hline \multicolumn{10}{|l|}{ US } \\
\hline Pre-2000 & & $\chi^{2}=4.54 *$ & & $x^{2}=9.25 * *$ & & $\chi^{2}=341.8 * *$ & & $\chi^{2}=14.1 * *$ & \\
\hline Post-2000 & & $x^{2}=.938$ & & $\chi^{2}=1.12$ & & $\chi^{2}=593.5 * *$ & & $\chi^{2}=.681$ & \\
\hline \multicolumn{10}{|l|}{ Canada } \\
\hline Pre-2000 & & $\chi^{2}=1.06$ & & $x^{2}=.106$ & & $\chi^{2}=8.9 * *$ & & $\chi^{2}=.527$ & \\
\hline Post-2000 & & $\chi^{2}=1.79$ & & $x^{2}=.729$ & & $x^{2}=136.1 * *$ & & $x^{2}=2.96 *$ & \\
\hline \multicolumn{10}{|l|}{ Japan } \\
\hline Pre-2000 & & $x^{2}=0.43$ & & $x^{2}=13.9 * *$ & & $\chi^{2}=113.7 * *$ & & $\chi^{2}=4.52 *$ & \\
\hline Post-2000 & & $x^{2}=0.35$ & & $x^{2}=17.7 * *$ & & $\chi^{2}=9.63 * *$ & & $\chi^{2}=10.5^{* *}$ & \\
\hline
\end{tabular}

$* * /(*)$ Indicates significance for $\mathrm{p}$-values $<.01 /(<.10)$

ROA $=$ return on assets, defined as operating income divided by average total assets

GrLTNOA = growth in long-term net operating assets, defined as the growth (annual change) in net long-term operating assets (plant assets, intangibles, other long term non-financial assets and liabilities)

$\mathrm{ACC}=$ accruals, defined as the growth (net change) in working capital accounts less current-period depreciation and amortization expense, divided by average total assets

$\mathrm{AR}=$ abnormal returns, defined as the difference between the reported return and the median of reported returns for the quintile of firms of the same size (determined by average assets). 


\section{CONCLUSION}

The cost allocation index developed for this study to measure conservative bias, along with international evidence using company data from the major exchanges in six countries, contribute to the literature on the effects of conservative accounting practices, especially regarding investment or growth in long-term assets. Moreover, the index indicates that there has been a shift in accounting practice in various countries. While there are numerous contributory factors, we believe that the global convergence of accounting standards is a key factor, and our results provide empirical support for the results of the changes documented by Sellhorn and Gornik-Tomasjewski (2006).

The results of this study demonstrate that the level of conservatism in accounting practices is a key factor related to the earnings persistence of growth in net operating assets and the relative persistence of its two components, accruals and the growth in long-term net operating assets. Our findings refute the assertion by FWY that the accrual anomaly described by Sloan (1996) is part of a general growth anomaly. The differential effect of conservatism on accruals and the growth in long-term net operating assets suggests that they are not merely two instances of the same growth anomaly phenomenon. Consistent with FWY, we find that, with the exception of Canada, international markets do not efficiently impound information conveyed by accruals and growth in long-term net operating assets.

Further research is needed to develop a comprehensive measure of conservative bias in accounting practices. Since depreciation and amortization are generally the largest components of accruals and are important in analyzing investment policy, we believe that conservatism cannot be properly assessed unless they are included. The recent changes in accounting standards regarding impairment offer new opportunities for this research. These changes, especially the movement in most countries toward applying a unified set of international accounting standards, elevate the importance of studying conservatism and other biases in accounting practice.

\section{AUTHOR INFORMATION}

Joan Hollister is an Associate Professor at the State University of New York at New Paltz. She earned her M.S. in accounting from the State University of New York at Albany and her Ph.D. from Union college. Her professional experience was at IBM in general accounting and as an inventory analyst. In addition to research regarding international financial accounting differences, her interests include topics related to accounting history and reporting for governmental and not-for-profit entities.

Victoria Shoaf received her Ph.D. from Baruch College, CUNY, in 1997, and is a Professor in the Department of Accounting and Taxation at the Peter J. Tobin College of Business at St. John's University. She is currently serving as the Associate Dean for Academic Affairs for the Tobin College of Business. Her prior experience includes controllership positions at several start-up and medium-sized firms. Her research focus is on domestic and international financial accounting and on business ethics and corporate governance issues related to the accounting profession.

\section{REFERENCES}

1. Ball, R., S. Kothari, and A. Robin. 2000. The effect of international institutional factors on properties of accounting earnings. Journal of Accounting and Economics, 29, 1-51.

2. Ballwieser, W. 2001. "Germany: Individual Accounts" in Transnational Accounting (2 ${ }^{\text {nd }}$ edition), v. 2, ed. D. Ordelheide and KPMG. New York: Palgrave Publishers, Ltd.

3. Basu, S. 1997. The Conservatism Principle and the Asymmetric Timeliness of Earnings. Journal of Accounting and Economics, 24, 3-37.

4. Beaver, W. and S. Ryan. 2005. Conditional and unconditional conservatism: concepts and modeling. Review of Accounting Studies, 10, 269-309.

5. Dechow, P. 1994. Accounting earnings and cash flows as measures of firm performance, the role of accounting accruals. Journal of Accounting and Economics, 18 (January), 3-42.

6. Easton, P. and J. Pae. 2004. Accounting conservatism and the relation between returns and accounting data. Review of Accounting Studies, 9, 495-521. 
7. Fairfield, P., Whisenant, J., and T. Yohn. 2003. Accrued earnings and growth: implications for future profitability and market mispricing. The Accounting Review, 78 (1), 253-371.

8. Feltham, G. and J. Ohlson. 1995. Valuation and clean surplus accounting for operating and financial activities. Contemporary Accounting Research, 11 (Spring), 689-731.

9. Givoly, D. and C. Hayn. 2000. The changing time-series properties of earnings, cash flows and accruals: has financial reporting become more conservative? Journal of Accounting \& Economics, 29, 287-320.

10. 2002. Rising conservatism: implications for financial analysis. Financial Analysts Journal, 58, 56-74.

11. Hollister, J. and V. Shoaf. 2007. An investigation of investors' use of reported cash flow and accrual information for eight countries. Journal of Applied Business Research, 23 (Fall), 69-78.

12. Mishkin, F. 1983. A Rational Expectations Approach to Macroeconomics: Testing Policy Effectiveness and Efficient-Markets Models. Chicago, IL: University of Chicago Press.

13. Monahan, S. 2005. Conservatism, growth and the role of accounting numbers in the fundamental analysis process. Review of Accounting Studies, 10, 227-260.

14. Nichols, D. and J. Wahlen. 2004. How do earnings numbers relate to stock returns? A review of classic accounting research with updated evidence. Accounting Horizons, 18, 263-287.

15. Ohlson, J. 1995. Earnings, book values, and dividends in equity valuation. Contemporary Accounting Research, 11 (Spring), 661-87.

16. Penman, S. 2004. Financial Statement Analysis and Security Valuation, $2^{\text {nd }}$ edition. Boston, MA: McGraw-Hill-Irwin.

17. Penman, S. and X. Zhang. 2002. Accounting conservatism, the quality of earnings, and stock returns. The Accounting Review, 77 (2), 237-264.

18. Sellhorn, T. and S. Gornik-Tomasjewski. 2006. Implication of the 'IAS regulation' for research into the international differences in accounting systems. Accounting in Europe, forthcoming.

19. Sloan, R. 1996. Do stock prices fully reflect information in accruals and cash flows about future earnings? The Accounting Review, 71, 289-315.

20. $\quad$ www.frc.org.uk/press/pub0166.html. Accessed 8/20/06.

21. www.iasplus.com/resource/0406ifrs japangaap.pdf. Accessed 8/20/06.

22. www.iasplus.com/restruct/euro2001.htm. Accessed 9/20/06. 
NOTES 